\title{
Analysis of the Effectiveness and Efficiency of the VA Solution on Offshore Pipelines and Ship Materials
}

\author{
Samson Nitonye, Prince Ugboga \\ Department of Marine Engineering, Rivers State University, Port Harcourt, Nigeria \\ Email: Nitonye.samson@ust.edu.ng
}

How to cite this paper: Nitonye, S. and Ugboga, P. (2020) Analysis of the Effectiveness and Efficiency of the VA Solution on Offshore Pipelines and Ship Materials. Open Journal of Marine Science, 10, 16-31. https://doi.org/10.4236/ojms.2020.101002

Received: October 9, 2019

Accepted: December 16, 2019

Published: December 19, 2019

Copyright $\odot 2020$ by author(s) and Scientific Research Publishing Inc. This work is licensed under the Creative Commons Attribution International License (CC BY 4.0).

http://creativecommons.org/licenses/by/4.0/

\section{cc) (i) Open Access}

\begin{abstract}
The analysis of the effectiveness and efficiency of Vernomia amydalina (VA) solution as an inhibitor on offshore pipeline and Ship materials (Steel) was carried out with the preparation of the specimen and the VA solution. The specimens were kept in a workable state and the VA Solution (inhibitor) prepared from $1200 \mathrm{~g}$ of bitter leaf was plucked, weighed and crushed separately. $600 \mathrm{cl}$ of water was added to each of the crushed leaves. The mixture was put in a filter cloth and squeezed with hand to filter out the active concentration ingredients responsible for corrosion inhibition, which produced a $2 \mathrm{M}$ concentration of VA extract solution. After the experiment was carried out the specimen was air-dried and weighed to determine the corrosion rate and weight loss. This was followed by the determination of the inhibitor efficiency at the different hours and at different percentage/concentration of the VA solution on the specimen. Results were obtained for different hours and at different percentage $(0 \%, 5 \%, 10 \%, 15 \%, 20 \%$ and $25 \%$ inhibitor $) /$ concentration of the VA solution and graphs plotted. It was observed that at the first week of exposure to corrosive medium there was a substantial reduction in weight of coupons but over the next three weeks there was a gradual decline in weight loss and the corrosion rate reduced evenly. It can be said that the percentage of inhibitor to corrosive medium is insufficient. From the graphs plotted, the inhibitor efficiency is considered high when the concentration of the VA solution is high, which implies a right percentage of inhibitor needs to be administered to obtain good efficiency of the solution. Hence as the weeks go by it was clear that the inhibitor was gradually losing its effectiveness. This means that inhibitors need to be added at regular intervals to sustain the effectiveness of the inhibitor. It is also of vital interest to apply the right concentration of inhibitor since $C R$ increases at high concentrations and temperature. This process did not take into consideration moving water.
\end{abstract}




\section{Keywords}

Vernomia amydalina, Inhibitors, Efficiency, Mild Steel, Corrosion, Environment

\section{Introduction}

Corrosion is defined as the deterioration and gradual destruction of the component of a material as a result of the chemical or electrochemical reactions of this material and its environment [1]. A general definition of corrosion is the degradation of material through environmental interactions; this includes manmade and naturally occurring structures [2]. For the purpose of the research, the focus is to analyze the effectiveness and efficiency of the VA solution as a corrosion inhibitor on offshore pipeline and ship materials, especially mild steel submerged in seawater of high salinity. These materials tend to corrode when exposed in aqueous environments which are either water or moist environment. This environment acts as the electrolyte and corrosion occur as an electrochemical process. Corrosion can be classified as dry and wet corrosion, chemical and electrochemical corrosion. Most corrosion problems encountered fall into five basic categories: uniform or general corrosion, localized corrosion, metallurgical induced corrosion, mechanically assisted corrosion and stress corrosion cracking [3]. These five basic categories of corrosion can be broken down into eight visually identifiable forms. They include the general or uniform corrosion, galvanic corrosion, crevice corrosion and pitting corrosion. Others are intergranular corrosion, microbiologically influenced corrosion, erosion corrosion and stress cracking corrosion [4]. Reactions in a typical galvanic cell are seen at the anode as $\mathrm{Fe} \rightarrow \mathrm{Fe}^{2+}+2 \mathrm{e}^{-}$and at the Cathode as $2 \mathrm{e}^{-}+2 \mathrm{H}^{+} \rightarrow \mathrm{H}_{2}$. In the Electrolyte it is $\mathrm{H}_{2} \mathrm{O} \rightarrow \mathrm{OH}^{-}+\mathrm{H}+\mathrm{Fe}^{2+}+2 \mathrm{OH}^{-} \rightarrow \mathrm{Fe}(\mathrm{OH})_{2}$. It is noteworthy that three conditions must exist for galvanic corrosion to occur. These include; electrochemically disparate metals must be present; the metals must be in electrical contact; and the metals must be open to an electrolyte.

\section{Forms of Corrosion}

\subsection{Galvanic Corrosion}

The most widespread corrosion in marine environments is Galvanic Corrosion. General corrosion appears as a continuous layer of corrosion over an entire surface area. It occurs more often for objects exposed to air such as piping and plates on exposed structures such as offshore platforms and ship. These are not found when objects are totally submerged in water. Galvanic corrosion occurs when two different types of metals are put into contact with each other while they are immersed in an electrolyte, such as seawater. Corrosion takes place between two different coupled metals due to voltage difference (potential) that ex- 
ist between them. The result is that one metal corrodes faster and other noble metal corrodes slower. The galvanic series is used to determine the potential for corrosion. The first sign of galvanic corrosion is paint blistering below the water line-a white powdery substance forms on the exposed metal areas. As the corrosion continues, the exposed metal areas will become deeply pitted, as the metal is eaten away [5]. In some working condition the galvanic corrosion is used to protect ship hulls by bolting zinc anodes to steel hulls [6].

\subsection{Inter-Granular Corrosion}

Intergranular corrosion is a microscopic form of corrosion that is caused by the potential difference between the grain boundaries of the metal and the grain bodies. When the grain bodies are anodic to grain boundaries corrosion occurs along the grain boundaries. The result is porous and a weakened structure. This type of corrosion is common for cast iron placed in sea water, and it occurs in brass having more than $15 \%$ zinc [7]. Intergranular or inter-crystalline means between grains or crystals. As the name suggests, this is a form of corrosive attack that progresses preferentially along inter-dendritic paths (the grain boundaries). Positive identification of this type of corrosion usually requires microstructure examination under a microscopy although sometimes is visually recognizable as in the case of weld decay [8] [9].

\subsection{Stress Corrosion Cracking}

Stress corrosion cracking (SCC) is an insidious type of corrosion that can occur when stainless steel develops very minute cracks from being under tensile stress. Most sailors know that a sailboat's rigging is one of the areas on the vessel that bears considerable load. The components on the rigging that are stressed while the vessel is under sail include the chain-plates, stem piece, and their bolting systems; backstay connections to the stern; toggles and clevis pins; rolled swages; tangs; the actual stays and shrouds, etc. [10].

The chemical environment that causes SCC for a given alloy is often one which is only mildly corrosive to the metal. Hence, metal parts with severe SSC can appear bright and shiny, while being filled with microscopic cracks. This factor makes it common for SCC to go undetected prior to failure [11]. Stresses can also be the result of the crevice loads due to stress concentration or can be caused by the type of assembly or residual stresses from fabrication, the residual stresses can be relieved by annealing or other surface treatments [12].

\subsection{Crevice Corrosion}

Crevice corrosion refers to the localized attack on a metal surface at, or immediately adjacent to, the gap or crevice between two joining surfaces. The gap or crevice can be formed between two metals or a metal and non-metallic material. Outside the gap or without the gap, both metals are resistant to corrosion. Crevice corrosion is initiated by a difference in concentration of some chemical 
constituents, usually oxygen, which set up an electromechanical concentration cell [13]. Chlorides concentrate inside the crevice (the anode), worsening the situation. Ferrous ions form ferric chloride and attack the stainless steel rapidly. The $\mathrm{pH}$ and the oxygen content are lower in the crevice than in the bulk water solution, just as they are inside a pit. The $\mathrm{pH}$ inside the crevice may be as low as 2 in a neutral solution. Once a crevice has formed, the propagation mechanism for crevice corrosion is the same as for pitting corrosion [14].

\subsection{Erosion Corrosion}

This corrosion occurs when sea water is flowing, and it is often found in bends and elbows of pipes. Corrosion due to cavitation is also caused due to sea water but the mechanism is different [15]. Erosion corrosion is a degradation of material surface due to mechanical action, often by impinging liquid, abrasion by slurry, particles suspended in fast flowing liquid or gas, bubbles or droplets, cavitation, etc. Mechanical erosion of the material, or protective (or passive) oxide layer on its surface enhanced corrosion of the material, if the corrosion rate of the material depends on the thickness of the oxide layer.

\subsection{Marine Growth}

A lot of hard growth occurs on all submerged metal. Marine organisms are attracted to the high electrical current generated by Zinc. Anodes with a lower $\mathrm{mV}$ potential will not attract the same level of growth. Marine fouling is the accumulation of micro- and macro-organisms on immersed surfaces which lead to economic, environmental or safety-related negative effects. Marine fouling generates surface roughness which increases the drag resistance of a ship moving through water and consequently increases fuel consumption and emission of greenhouse gases. Heavy calcareous fouling may result in powering penalties of more than $85 \%$. Moreover, even slime films can lead to significant increases in resistance and powering (approximately 20\%) [16].

Another effect of marine fouling is the deterioration of coatings such as favored corrosion. Settlement of fouling generates an increase of the frequency of dry-docking operations either because of the need of additional hull cleaning or even in costly additional coating replacement or hull repair. Fouled vessels are the most common vectors of marine species which attach themselves to the ship hull and can be displaced in foreign areas leading to the introduction of invasive, non-indigenous species into non-native environments [17].

\subsection{Atmospheric Corrosion}

Atmospheric corrosion refers to the corrosive action that occurs on the surface of a metal in contact with an atmospheric environment. It is a complex process involving many interacting and constantly varying factors, such as meteorological factors, air pollutants, metallurgical factors (including metal type, microstructure and morphology), distance from the sea etc. [18]. Atmospheric corro- 
sion has become a major subject of research for decades now and there is substantial knowledge today about atmospheric corrosion and the processes involved. However, most available field exposure data have been obtained in regions with temperate climate [19].

\subsection{Corrosion Prevention Processes}

The protection of materials especially for mild steel structures from corrosion is achieved by several methods, namely, use of anti-fouling paint, cathodic protection and the use of corrosion inhibitors. Cathodic protection to a metal structure can be done by either the technique of impressed current or using a sacrificial anode. Cathodic protection is achieved by making a metal to work as a cathode in an electrochemical cell. Sacrificial anodes are highly active metals with more negative electrochemical potential than the other metal which they are used to protect [20]. Among these methods, corrosion inhibition is the most economical, practical, and convenient technique to control corrosion on metals in aqueous environment.

Methods of corrosion protection;

- Anti-corrosion paints-metallic/organic;

- Cathodic protection-ICCP (Impressed Current Cathodic Protection);

- Cathodic protection-Sacrificial Anodes;

- Inhibitors.

\subsection{Inhibitors}

According to, the definition of inhibitor favored by the National Association of Corrosion Engineers (NACE) is: a substance which Inhibitors retards corrosion when added to an environment in small concentrations and functions in one or more ways to control corrosion; by adsorption of a thin film onto the surface of a corroding material, by inducing the formation of a thick corrosion product, or by changing the characteristics of the environment resulting in reduced aggressiveness [21] [22].

\subsubsection{Mechanism of Corrosion Inhibitor}

Every corrosion inhibitor should be capable of establishing a stable bond with the metal surface in each environment of a certain range of acidity and pressure and create an impenetrable layer for corroding ions. No attempt will be made here to provide details of inhibitor mechanisms, as there are several excellent works done on the subject matter [23] [24]. When an aqueous solution of one of the substituted ammonium nitrites is in contact with a clean iron surface, preferential adsorption occurs, and the resulting film prevents the water from attacking the ferrous metal at $100^{\circ} \mathrm{F}$. The optimum inhibitor concentration at $100^{\circ} \mathrm{F}$ has been found to be $0.01 \%$ by weight. At higher temperatures, higher inhibitor concentrations would be required. However, if uninhibited water washes the surface of the inhibited steel, it dissolves the adsorbed film allowing corrosion to occur [25]. 


\subsubsection{Sources of Corrosion Inhibitors}

There are various sources of corrosion inhibitors. Most of the well-known inhibitors are organic compounds containing electronegative functional groups and $\pi$-electrons in conjugated double or triple bonds and hence exhibit good inhibitive properties by supplying electrons through $\pi$-orbitals [26]. There is also a specific interaction between functional groups containing heteroatoms like nitrogen, sulfur, oxygen having free lone pair of electrons, and the metal surface, which play an important role in inhibition. When both features combine, increased inhibition can be observed [27].

\subsubsection{Organic Corrosion Inhibitors}

Polar-type rust inhibitors for steel in non-aqueous fluids revealed that both soaps and amine-acid complexes acted as rust inhibitors in oils through the release of organic acids which had been held by association [25]. It is shown that most effective rust-inhibiting additives are those which remain in the oil in the most highly dispersed colloidal condition and which release those which organic acids having the greatest ability to inhibit rusting of steel. The most effective acids are those which react with the iron surface to form soaps in situ.

\subsubsection{Green Corrosion Inhibitors}

Plant extracts have potential to replace synthetic organic and inorganic inhibitors given their success story in literature. The mechanism of action of green inhibitors depends on the structure of the active ingredient and thus many researchers have to date postulated many theories to explain this phenomenon [26]. The active constituents of natural inhibitors vary from one plant species to another, but their structures are closely related to their organic counterparts. For example, garlic, castor seed, carrot, mustard seeds etc. contains alkaloid berberine which has a long chain of aromatic rings and an $\mathrm{N}$ atom in the ring that serves as inhibitive effects [28]. In this work a consideration is made on the Vernomia amydalina (VA) inhibitor, to see its effectiveness and efficiency on pipelines found in a marine environment.

\section{Materials and Methods}

Vernomia amydalina (VA) inhibitor is a plant as shown in Figure 1, an extract classified under green corrosion Inhibitors. There are several plant extract corrosion inhibitors for corrosion prevention, but VA was chosen so that the research could identify its effectiveness and efficiency on corrosion control.

A laboratory test was conducted which provided data and facts for the appropriate material selection for use in ship hull in saltwater environments, corrosion control and study of corrosion mechanisms. The standard employed is the ASTM G13: standard recommended practice for laboratory immersion corrosion testing of materials [29]. This recommended practice which is based upon NACE standard TM-10-69, "test method laboratory corrosion testing of metals for the process industries" clearly describes the experimental procedure to be used [30] [31]. 


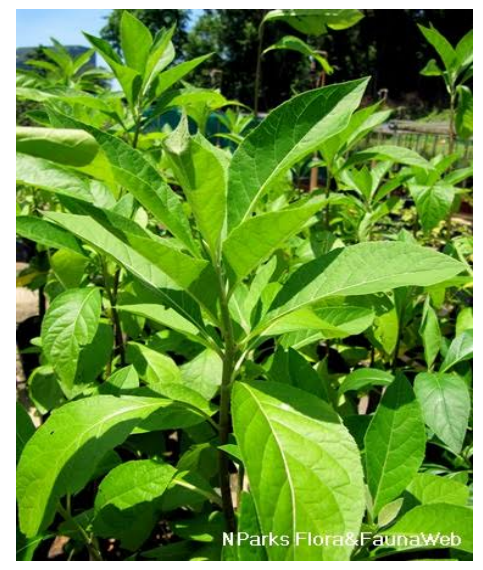

Figure 1. Vernomia amydalina (VA) bitter leaf.

\subsection{Materials}

The test apparatus used include the corrosion testing specimens; corrosive medium-seawater, $2 \mathrm{M}$ concentration of both VA (bitter leaf) extract solution, distilled water, plastic bowl, top-loading electronic chemical weighing balance, measuring cylinder, beakers, rubber threads, acetone, wooden sticks. Mild Steel sheets were used as the corrosion testing specimens. It was obtained from a fabrication store. The shape and size of specimen; the specimen was machined to have a large surface area to mass ratio and a small ratio of edge area to total area used. A square specimen of dimension $25 \times 20 \times 1 \mathrm{~mm}$ and a $2.5 \mathrm{~mm}$ hole was bored near the top center of the specimens [30] [32].

\subsection{Methods}

1) Total surface area of each specimen is given by the relation in Equation:

$$
A=2(L B+B H+L H)+\pi d H \frac{\pi d^{2}}{2} \quad[33]
$$

where;

$L=$ length of the specimen;

$H=$ thickness of the specimen;

$d=$ bore diameter and;

$B=$ breadth of the specimen;

$\pi=22 / 7$;

$A=$ Total Surface of the specimen.

2) In order to obtain exact results, the specimens were kept in a workable state and the following steps were taken to prepare each specimen:

a) All cuts and sheared edges were ground out to prevent them from becoming sites for preferential attack.

b) Finishing of the specimen surface with grit abrasive paper (sandpaper).

c) Rinsing of the specimens in distilled water.

d) Degreasing of specimen in acetone and air dried.

e) Upon drying, the specimen was immediately weighed to obtain their initial weights. 
3) The specimen was labelled for the sake of comparison.

4) To prepare the inhibitor, $1200 \mathrm{~g}$ of bitter leaf was plucked, weighed and crushed separately. $600 \mathrm{cl}$ of water was added to each of the crushed leaves. The mixture was put in a filter cloth and squeezed with hand to filter out the active concentration ingredients responsible for corrosion inhibition. This produced a $2 \mathrm{M}$ concentration of VA extract solution.

5) The experimental procedure used was seawater of $7.25 \mathrm{pH}$. At the end of every week (168 hours) the following steps was taken to obtain readings:

a) Removal of specimen from corrosive media, Observation and recording of appearance of the specimen noting sites and locations of deposits and variation in types of deposits.

b) Cleaning of specimen with white handkerchief or tissue paper.

c) Washing of specimen with distilled water.

d) Scrubbing of specimen with a soft brush.

e) Dipping the specimen into acetone after washing.

f) Removing to air-dry and weighed.

6) Determination of $C R$ : The method used to calculate the corrosion rate is as follows; Mass loss has been used due to general corrosion and material has not been internally attacked. The $C R$ in $\mathrm{mm} / \mathrm{yr}$ is given by the relation in Equation.

$$
C R=\frac{K \times W}{A \times T \times D} \quad[34]
$$

where,

$W=$ mass loss $(\mathrm{g})$,

$K=C R$ constant $=8.76 \times 10^{4}$,

$A=$ area of specimen $\left(\mathrm{cm}^{2}\right)$,

$D_{1}=$ density of MS $\left(\mathrm{g} / \mathrm{cm}^{2}\right)=7.86 \mathrm{~g} / \mathrm{cm}^{3}$,

$T=$ time of exposure in hours and

7) Change in Weight

$$
\Delta W=(\text { weight at time, } t=0)-(\text { weight at time, } t-i)
$$

where:

$i=1-5$ weeks.

8) Inhibitor Efficiency (IE) $=\frac{C R_{1}-C R_{2}}{C R_{1}} \times 100 \%$ where,

$C R_{1}=$ Corrosion rate in the absence of inhibitor and

$C R_{2}=$ Corrosion rate in the presence of inhibitor.

The result was tabulated and compared by plotting a graph using EXCEL.

\section{Results and Discussion}

\subsection{Results}

The values of Tables 1-5 were plotted in a graph of WL against time and $C R$ against time and Efficiency of Inhibitor against Concentration of inhibitor as shown in Figures 2-9. This is to aid easy comparison of the rate of corrosion 
Table 1. Data for WL, $C R$ and VA inhibitor efficiency on MS samples for 7 days.

\begin{tabular}{cccccc}
\hline $\begin{array}{c}\text { Inhibitor } \\
\text { Conc. }\end{array}$ & $\begin{array}{c}\text { Initial Weight } \\
(\mathrm{g})\end{array}$ & $\begin{array}{c}\text { Final Weight } \\
(\mathrm{g})\end{array}$ & $\begin{array}{c}\text { Change in } \\
\text { Weight }(\mathrm{g})\end{array}$ & $\begin{array}{c}\text { Corrosion Rate } \\
(\mathrm{mm} / \mathrm{yr})\end{array}$ & $\begin{array}{c}\text { Inhibitor } \\
\text { Efficiency (\%) }\end{array}$ \\
\hline $0 \%$ & 6.8217 & 6.6139 & 0.2078 & 0.6187 & 0 \\
$5 \%$ & 6.6576 & 6.6321 & 0.0255 & 0.0759 & 87.73 \\
$10 \%$ & 6.2922 & 6.2519 & 0.0403 & 0.1199 & 80.62 \\
$15 \%$ & 6.7667 & 6.766 & 0.0007 & 0.0021 & 99.66 \\
$20 \%$ & 6.6391 & 6.6372 & 0.0019 & 0.0056 & 99.09 \\
$25 \%$ & 6.5976 & 6.5963 & 0.0013 & 0.0038 & 99.38 \\
\hline
\end{tabular}

Table 2. Data for WL, $C R$ and VA inhibitor efficiency on MS samples for 14 days.

\begin{tabular}{cccccc}
\hline $\begin{array}{c}\text { Inhibitor } \\
\text { Conc. }\end{array}$ & $\begin{array}{c}\text { Initial Weight } \\
(\mathrm{g})\end{array}$ & $\begin{array}{c}\text { Final } \\
\text { Weight }(\mathrm{g})\end{array}$ & $\begin{array}{c}\text { Change in } \\
\text { Weight }(\mathrm{g})\end{array}$ & $\begin{array}{c}C R \\
(\mathrm{~mm} / \mathrm{yr})\end{array}$ & $\begin{array}{c}\text { Inhibitor } \\
\text { Efficiency (\%) }\end{array}$ \\
\hline $0 \%$ & 6.8217 & 6.6120 & 0.2097 & 0.3122 & 0 \\
$5 \%$ & 6.6576 & 6.6239 & 0.0337 & 0.0501 & 83.95 \\
$10 \%$ & 6.2922 & 6.2487 & 0.0435 & 0.0647 & 79.27 \\
$15 \%$ & 6.7667 & 6.7520 & 0.0147 & 0.0218 & 93.01 \\
$20 \%$ & 6.6391 & 6.6344 & 0.0047 & 0.0069 & 97.78 \\
$25 \%$ & 6.5976 & 6.5925 & 0.0051 & 0.0075 & 97.59 \\
\hline
\end{tabular}

Table 3. Data for WL, $C R$ and VA inhibitor efficiency on MS samples for 21 days.

\begin{tabular}{cccccc}
\hline $\begin{array}{c}\text { Inhibitor } \\
\text { Conc. }\end{array}$ & $\begin{array}{c}\text { Initial Weight } \\
(\mathrm{g})\end{array}$ & $\begin{array}{c}\text { Final } \\
\text { Weight }(\mathrm{g})\end{array}$ & $\begin{array}{c}\text { Change in } \\
\text { Weight }(\mathrm{g})\end{array}$ & $\begin{array}{c}C R \\
(\mathrm{~mm} / \mathrm{yr})\end{array}$ & $\begin{array}{c}\text { Inhibitor } \\
\text { Efficiency (\%) }\end{array}$ \\
\hline $0 \%$ & 6.8217 & 6.5345 & 0.2872 & 0.2872 & 0 \\
$5 \%$ & 6.6576 & 6.6149 & 0.0427 & 0.0423 & 85.27 \\
$10 \%$ & 6.2922 & 6.2453 & 0.0469 & 0.0465 & 83.80 \\
$15 \%$ & 6.7667 & 6.7511 & 0.0156 & 0.0154 & 94.63 \\
$20 \%$ & 6.6391 & 6.6120 & 0.0271 & 0.0268 & 90.66 \\
$25 \%$ & 6.5976 & 6.5917 & 0.0059 & 0.0058 & 97.98 \\
\hline
\end{tabular}

Table 4. Data for WL, $C R$ and VA inhibitor efficiency on MS samples for 28 days.

\begin{tabular}{cccccc}
\hline $\begin{array}{c}\text { Inhibitor } \\
\text { Conc. }\end{array}$ & $\begin{array}{c}\text { Initial Weight } \\
(\mathrm{g})\end{array}$ & $\begin{array}{c}\text { Final } \\
\text { Weight }(\mathrm{g})\end{array}$ & $\begin{array}{c}\text { Change in } \\
\text { Weight }(\mathrm{g})\end{array}$ & $\begin{array}{c}C R \\
(\mathrm{~mm} / \mathrm{yr})\end{array}$ & $\begin{array}{c}\text { Inhibitor } \\
\text { Efficiency (\%) }\end{array}$ \\
\hline $0 \%$ & 6.8217 & 6.5310 & 0.2907 & 0.2164 & 0 \\
$5 \%$ & 6.6576 & 6.6127 & 0.0449 & 0.0334 & 84.56 \\
$10 \%$ & 6.2922 & 6.2451 & 0.0471 & 0.0350 & 83.82 \\
$15 \%$ & 6.7667 & 6.7507 & 0.0160 & 0.0119 & 94.50 \\
$20 \%$ & 6.6391 & 6.6090 & 0.0301 & 0.0224 & 89.64 \\
$25 \%$ & 6.5976 & 6.5900 & 0.0076 & 0.0056 & 97.41 \\
\hline
\end{tabular}




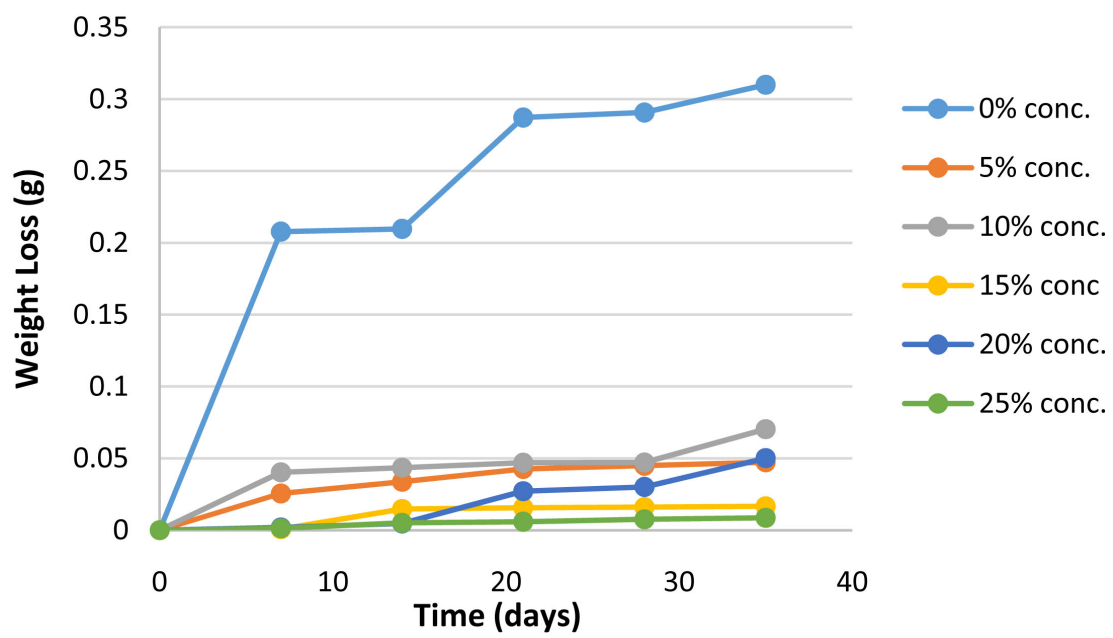

Figure 2. Weight loss against time.

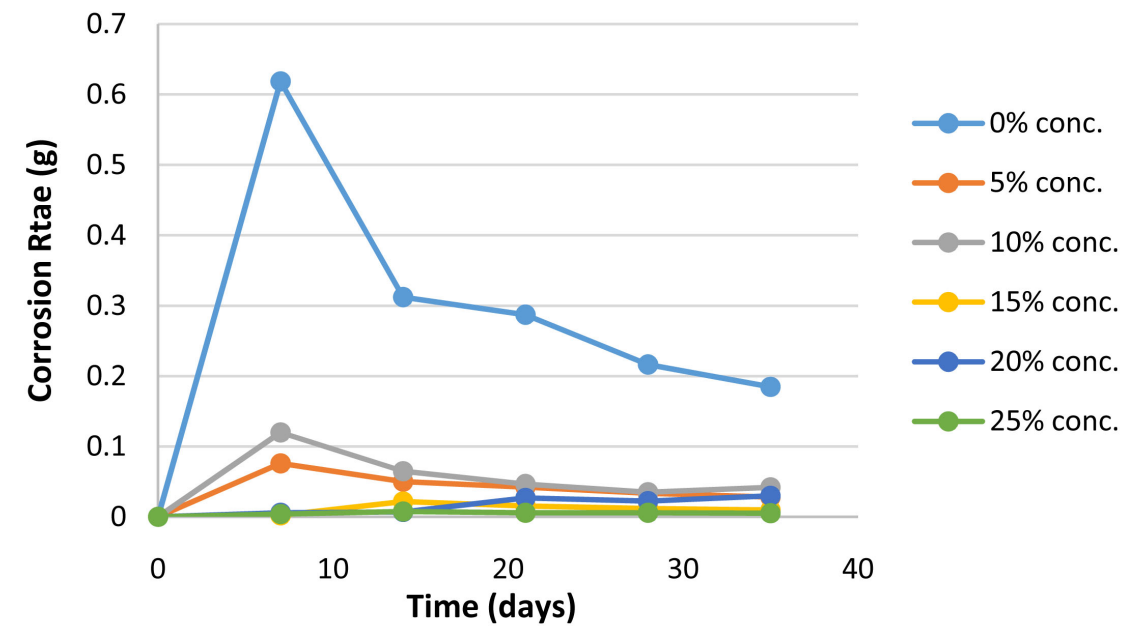

Figure 3. Corrosion rate against time.

Variation of inhibition efficiency with VA extract

Concentration for different weeks

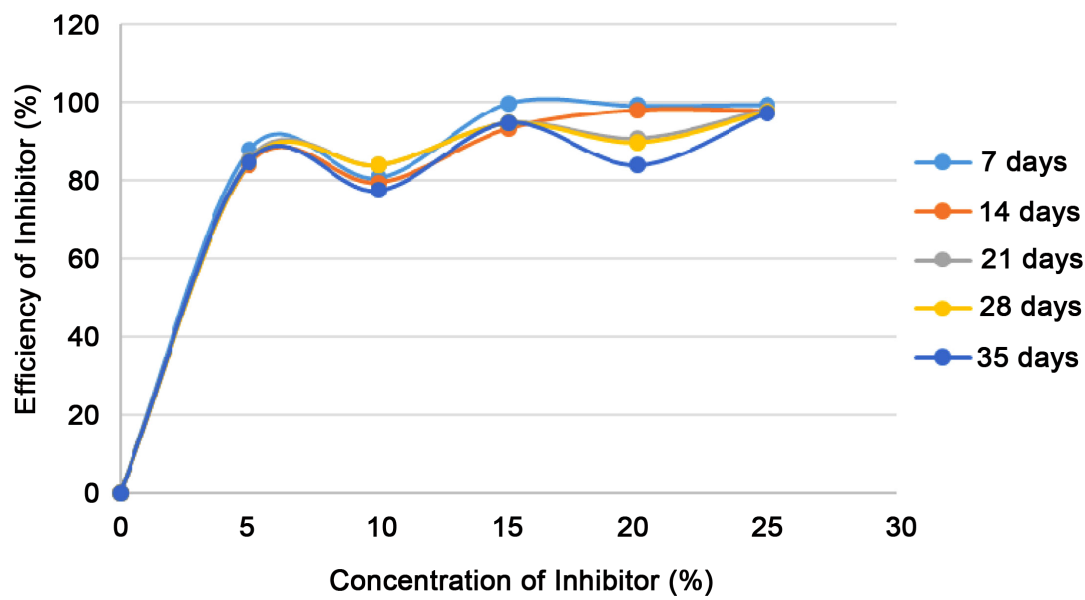

Figure 4. Inhibitor efficiency against VA extract concentration for different weeks. 


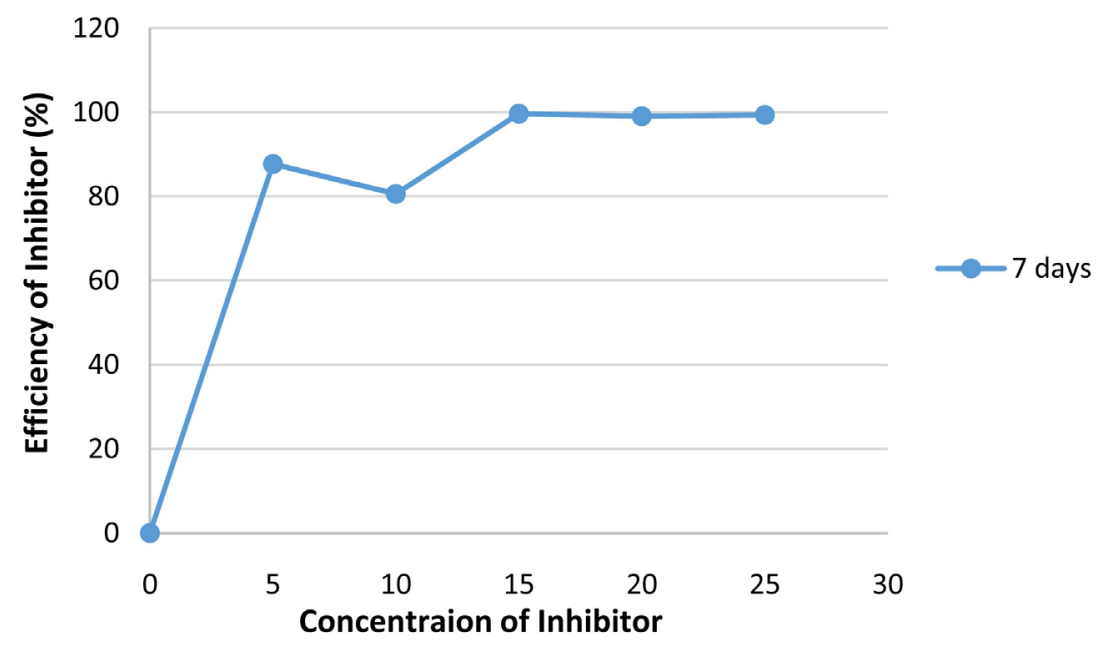

Figure 5. Efficiency of inhibitor for 7 days (168 hours).

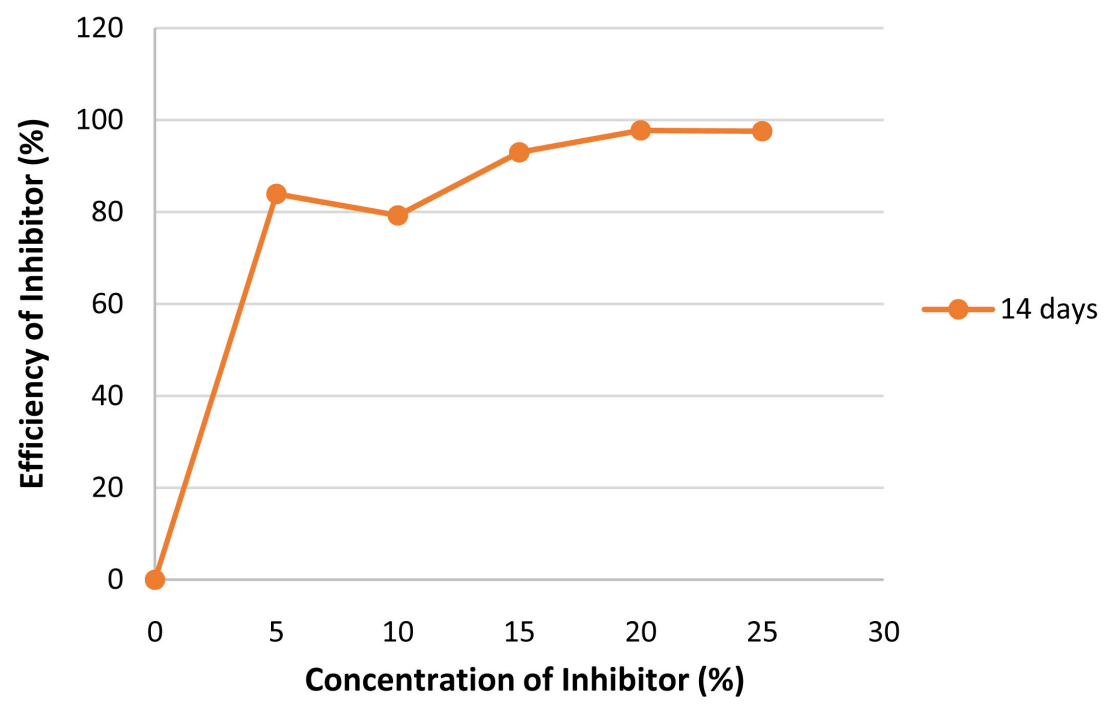

Figure 6. Efficiency of inhibitor for 14 days (336 hours).

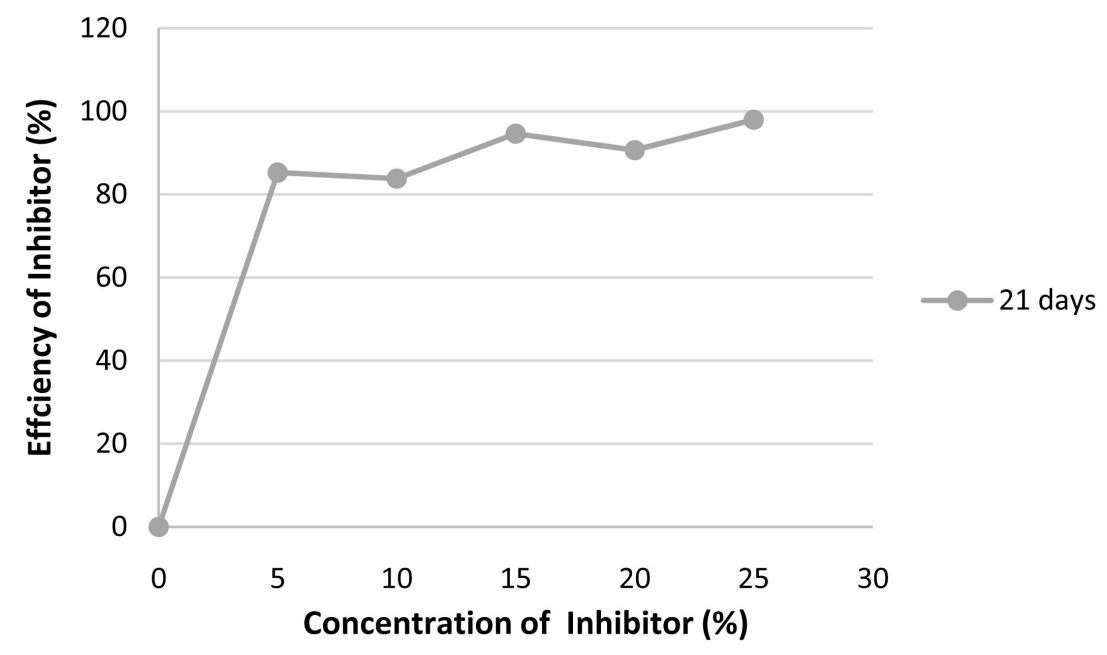

Figure 7. Efficiency of inhibitor for 21 days (504 hours). 


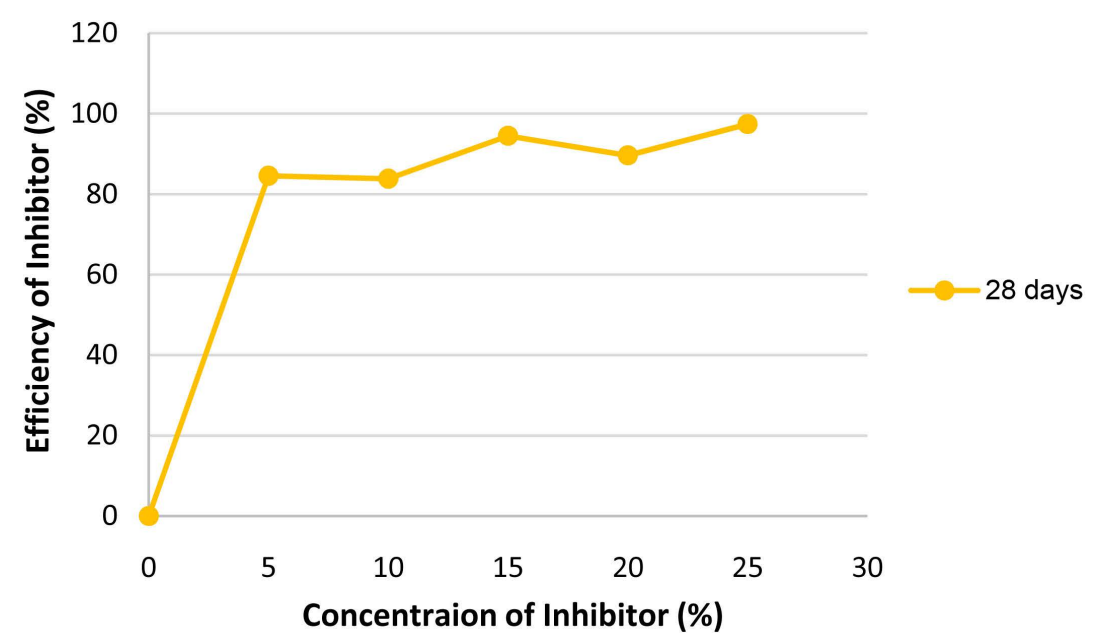

Figure 8. Efficiency of inhibitor for 28 days (672 hours).

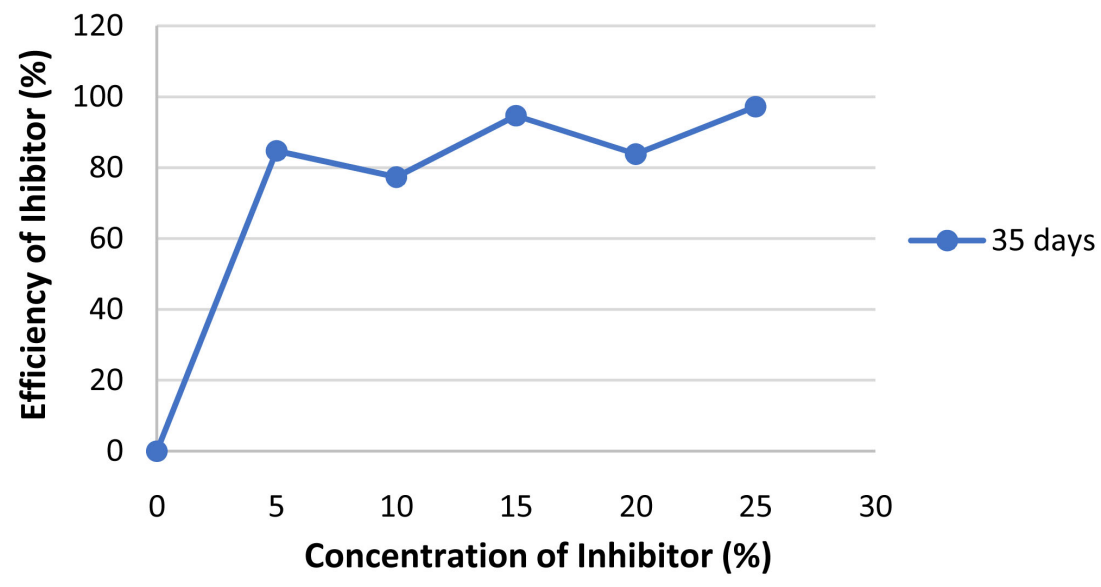

Figure 9. Efficiency of inhibitor for 35 days (840 hours).

Table 5. Data for WL, $C R$ and VA inhibitor efficiency on MS samples for 35 days.

\begin{tabular}{cccccc}
\hline $\begin{array}{c}\text { Inhibitor } \\
\text { Conc. }\end{array}$ & $\begin{array}{c}\text { Initial Weight } \\
(\mathrm{g})\end{array}$ & $\begin{array}{c}\text { Final } \\
\text { Weight }(\mathrm{g})\end{array}$ & $\begin{array}{c}\text { Change in } \\
\text { Weight }(\mathrm{g})\end{array}$ & $\begin{array}{c}C R \\
(\mathrm{~mm} / \mathrm{yr})\end{array}$ & $\begin{array}{c}\text { Inhibitor } \\
\text { Efficiency (\%) }\end{array}$ \\
\hline $0 \%$ & 6.8217 & 6.5117 & 0.3100 & 0.1846 & 0 \\
$5 \%$ & 6.6576 & 6.6103 & 0.0473 & 0.0281 & 84.77 \\
$10 \%$ & 6.2922 & 6.2219 & 0.0703 & 0.0418 & 77.37 \\
$15 \%$ & 6.7667 & 6.7501 & 0.0166 & 0.0098 & 94.69 \\
$20 \%$ & 6.6391 & 6.5890 & 0.0501 & 0.0298 & 83.85 \\
$25 \%$ & 6.5976 & 6.5890 & 0.0086 & 0.0051 & 97.23 \\
\hline
\end{tabular}

and weight loss of each sample in the different percentages of inhibiting solution and as well the inhibitor efficiency.

\subsection{Discussion}

It was observed that at the first week of exposure to corrosive medium there was 
a substantial reduction in weight of coupons but over the next three weeks there was a gradual decline in weight loss and the corrosion rate reduced evenly, although the medium is inhibited there is still a good percentage of corrosion of coupons. It can be said that the percentage of inhibitor to corrosive medium (sea water) is insufficient. Figure 2 and Figure 3 represent the graph of WL against time and $C R$ against time for MS samples with $0 \%, 5 \%, 10 \%, 15 \%, 20 \%$ and $25 \%$ inhibitor respectively. This shows that there is an effective control of corrosion in the coupons over the period of the experiment. It represents an optimal inhibiting process to a great extent. Figures 4-9 represent the graph of Inhibitor Efficiency against the VA extract concentration for different weeks. It is observed that after the first 3 weeks of testing there is a great decrease in $C R$. This explains that even with increasing percentage of inhibitor the $C R$ is not reduced correspondingly. So, a right percentage of inhibitor needs to be administered. WL determination has a number of attractive features that account for its sustained popularity, some of the advantages are as follow; it is simple because no sophisticated instrumentation is required to obtain a result, it is direct because a direct measurement is obtained, with no theoretical assumption or approximations, it is also versatile because it is applicable to all corrosive environments, and gives information on all forms of corrosion and it is visual because inspection can be undertaken. Furthermore, corrosion deposits can be observed and analyzed, weight loss can be readily determined, and rate easily calculated, localized corrosion can be identified and measured, and inhibitor performance can be easily assessed.

\section{Conclusion}

From Figure 2 we can see the effectiveness and the efficiency of the VA Solution when introduced in a corrosive environment. This shows that the weight loss is the least when the concentration is $25 \%$ which is less than 0.02 . It was also observed that the introduction of the VA solution reduced the weight loss to less than 0.1 at different concentration level while without the VA solution it was more than $0.3 \mathrm{~g}$ of the material. The research work of the effectiveness and efficiency of the VA Solution on offshore pipeline shows that optimum effectiveness and efficiency was observed to be between $20 \%-25 \%$ of the Concentration of the VA Solution and during the first four weeks of testing. At the fifth week, the inhibitor was gradually losing its effectiveness as shown in Figure 4. This means that more inhibitor needs to be introduced into the system at regular intervals to sustain the effectiveness of the VA solution as an inhibitor. It is also of vital interest to apply the right concentration of VA solution since $C R$ increases at high concentrations and temperature.

\section{Acknowledgements}

The authors appreciate the contribution of Prof Ezenwa A Ogbonnaya and Ofonime $\mathrm{U}$ Emmanuel in making this work a success. 


\section{Conflicts of Interest}

The authors declare no conflicts of interest regarding the publication of this paper.

\section{References}

[1] Nitonye, S., Emmanuel, U.O. and Ezenwa, A.O. (2018) Combating Corrosion in Transmission Pipelines in Marine Environment Using Vernomia Amydalina as Inhibitor. Open Journal of Marine Science, 8, 450-472. https://doi.org/10.4236/ojms.2018.84025

[2] Fontana, M.G. and Greene, N.D. (2010) Corrosion Engineering. Materials Science and Engineering, University of Minnesota, Minneapolis, MN.

[3] Solomon, M.M. and Umoren, S.A. (2015) Enhanced Corrosion Inhibition Effect of Polypropylene Glycol in the Presence of Iodide Ions at Mild Steel/Sulphuric Acid Interface. Journal of Environmental Chemical Engineering, 3, 1812-1826. https://doi.org/10.1016/j.jece.2015.05.018

[4] Iduk, U. and Samson, N. (2015) Effects and Solutions of Marine Pollution from Ships in Nigerian Waterways. International Journal of Scientific and Engineering Research, 6, 782-792. http://www.ijser.org

[5] Singh, P., Srivastava, V. and Quraishi, M.A. (2016) Novel Quinoline Derivatives as Green Corrosion Inhibitors for Mild Steel in Acidic Medium: Electrochemical, SEM, AFM, and XPS Studies. Journal of Molecular Liquids, 216, 164-173. https://doi.org/10.1016/j.molliq.2015.12.086

[6] Paul Guyer, J. (2014) An Introduction to Cathodic Protection Principles. Course No. E05-006.

[7] Dunn, D.S., Bogart, M.B., Brossia, C.S. and Cragnolino, G.A. (2000) Corrosion of Iron under Alternating Wet and Dry Conditions. Corrosion, 56, 470-481. https://doi.org/10.5006/1.3280551

[8] Singh, R. (2014) Corrosion Control and Monitoring. In: Corrosion Control for Offshore Structures. Cathodic Protection and High Efficiency Coating, Elsevier, Amsterdam, 41-44. https://doi.org/10.1016/B978-0-12-404615-3.00003-6

[9] Brossia, C.S. and Cragnolino, G.A. (2000) Corrosion in the Petrochemical Industry, ASM International Material Park Ohia. https://www.asminternational.org/

[10] Tuaweri, T.J., Ogbonnaya, E.A. and Onyemaobi, O.O. (2015) Corrosion Inhibition of Heat-Treated Mild Steel with Neem Leaves Extract in a Chloride Medium. International Journal of Research in Engineering and Technology, 4, 404-409. https://www.ijret.org https://doi.org/10.15623/ijret.2015.0406069

[11] John, B., Watchman, W., Roger Cannon, M. and Matthewson, J. (2009) Mechanical Properties of Ceramics. John Wiley \& Sons, Inc., New York.

[12] Prager, M. (2009) The Properties of Cast Alloys for Large Marine Propellers. ASME Cast Metals for Structural and Pressure.

[13] Abdul-Wahab, S.A., Bakheit, C.S., Siddiqui, R.A. and Al-Alawi, S.M. (2004) Atmospheric Corrosion of Metals. Corrosion, 5, 195-204.

[14] Sato, S. and Nagata, K. (1978) Factors Affecting Corrosion and Fouling of Metal Condenser Tubes of Copper Alloys and Titanium. Sumitomo Light Metal Technical Reports, 19, 83.

[15] Samson, N. and Ogbonnaya, E.A. (2015) Optimized Condition Monitoring Model 
for Performance Evaluation of a Shell and Tube Heat Exchanger. International Research Journal in Engineering, Science and Technology, 12, 21-34. https://www.researchgate.net/publication/281399360

[16] Nitonye, S. and Adumene, S. (2015) Predictive Analysis of Bare-Hull Resistance of a 25,000 DWT Tanker Vessel. International Journal of Engineering and Technology, 5, 194-198. http://www.ijet.journal.org

[17] Samson, N. (2015) Stress and Resistance Analysis for the Design of a Work Barge. International Journal of Scientific and Engineering Research, 6, Article ID: 1064974. http://www.ijser.org

[18] Ogbonna, I.J. (2008) Mechanism and Modeling of Atmospheric Corrosion of Zinc Coated Iron Sheets along the South-Eastern Coast of the Niger Delta. Ph.D. Thesis, University of Calabar, Calabar.

[19] Tzanis, C., Varotsos, C., Christodoulakis, J., Tidblad, J., Ferm, M., Ionescu, A., Lefevre, R.-A., Theodorakopoulou, K. and Kreislova, K. (2011) On the Corrosion and Soiling Effects on Materials by Air Pollution in Athens, Greece. Atmospheric Chemistry and Physics, 11, 12039-12048. http://www.atmos-chem-phys.net https://doi.org/10.5194/acpd-10-29599-2010

[20] Sastri, V.S. (2014) Corrosion Processes and the Use of Corrosion Inhibitors in Managing Corrosion in Underground Pipelines. In: Underground Pipeline Corrosion: Cathodic Protection and High Efficiency Coating, 127-165.

https://doi.org/10.1533/9780857099266.1.127

[21] Hamner, N.E. (1964) NACE Glossary of Corrosion Terms. CORROSION, 20, 267t-268t. https://doi.org/10.5006/0010-9312-20.8.267t

[22] Alaneme, K.K., Olusegun, S.J. and Adelowo, O.T. (2016) Corrosion Inhibition and Adsorption Mechanism Studies of Hunteria umbellata Seed Husk Extracts on Mild Steel Immersed in Acidic Solutions. Alexandria University, Egypt. https://doi.org/10.1016/j.aej.2015.10.009

[23] Jirapure, S.C. and Borade, A.B. (2016) Naval Corrosion-Causes and Prevention. International Journal of Engineering Sciences \& Research Technology, 3, 263-268.

[24] Ferrara, R.J. and Gudas, J.P. (1972) Corrosion Behavior of Copper-Base Alloys with Respect to Velocity. Proceedings of 3rd International Congress on Marine Corrosion and Fouling, National Bureau of Standards, Gaithersburg, MD, 2-6 October 1972.

[25] Baker, H.R. and Zisman, W.A. (1951) Liquid and Vapor Corrosion Inhibitors. U.S. Naval Research Laboratory Report NRL-3824.

[26] Yadav, M., Gope, L., Kumari, N. and Yadav, P. (2016) Corrosion Inhibition Performance of Pyranopyrazole Derivatives for Mild Steel in HCL Solution: Gravimetric, Electrochemical and DFT Studies. Journal of Molecular Liquids, 216, 78-86. https://doi.org/10.1016/j.molliq.2015.12.106

[27] Beavers, A.J., Peabody, A.W. and Little, B.J. (2007) Control of Pipeline Corrosion. NACE International, Houston, TX.

[28] Ekine, A.S. and Emujakporue, G.O. (2010) Investigation of Corrosion of Buried Oil Pipeline by the Electrical Geophysical Methods. Journal of Applied Science and Environmental Management, 14, 63-65.

[29] ASTM G13/G13M-13 (2013) Standard Test Method for Impact Resistance of Pipeline Coatings (Limestone Drop Test). ASTM International, West Conshohocken, PA. http://www.astm.org

[30] Samson, N., Nwaoha, T.C. and Emmanuel, O. (2018) Comparative Analysis of the 
Effect of Vernonia Amygdaline on Subsea Transmission Pipeline. Journal of Mechanical and Energy Engineering, 2, 269-276. http://www.jmee.tu.koszalin.pl https://doi.org/10.30464/jmee.2018.2.4.269

[31] Sully, J.R. and Taylor, D.W. (2004) Electrochemical Methods of Corrosion Testing Metals Handbook. Volume 13, McGraw-Hill, Inc., New York.

[32] Tuaweri, T.J. and Ogbonnaya, E.A. (2017) Corrosion Inhibition Characteristics of Vernonia Amygdalina (Bitter Leaf) on Mild Steel in Seawater. Journal of Science and Engineering Research, 4, 6-13. http://www.jsaer.com/

[33] Raouf, A.A. and Ahmed, M.F. (2011) The General Equation of the Pipe to Soil Potential at All Humidity Conditions by the Use of Both Soil Factor and Stray Potential of the Pipe-Soil Earthing Grid System. Journal of American Science, 7, 787-795.

[34] Ahmed, I., Islam, A. and Ali, N. (2017) Determination of Corrosion Rate of Mild Steel in Different Medium Measuring Current Density. 4th International Conference on Mechanical Engineering and Renewable Energy, Chittagong, Bangladesh, 18-20. https://www.researchgate.net/publication/321998150 